\title{
Genesis and Behavior of Sodic Soils in Humid Climates
}

\author{
Michael Aide \\ Department of Agriculture, Southeast Missouri State University, Cape Girardeau, Missouri, USA \\ Email: mtaide@semo.edu
}

How to cite this paper: Aide, M. (2022) Genesis and Behavior of Sodic Soils in Humid Climates. Agricultural Sciences, 13, 150-164. https://doi.org/10.4236/as.2022.132012

Received: January 13, 2022

Accepted: February 7, 2022

Published: February 10, 2022

Copyright (C) 2022 by author(s) and Scientific Research Publishing Inc. This work is licensed under the Creative Commons Attribution International License (CC BY 4.0)

http://creativecommons.org/licenses/by/4.0/

\begin{abstract}
Sodic soils are typically located in semi-arid to arid climates. However, sodic soils in continental humid climates are rare. As with sodic soils in dry climates, sodic soils in wetlands pose management difficulties for agriculture, forestry, or wild-life habitat. The typical practice of gypsum application is problematic given inability to provide drainage. Natraqualfs located in southeastern Missouri present an acid argillic horizon superimposed on a natric horizon, where the exchangeable sodium percentage and an alkaline reaction are characteristic attributes. Ferrolysis is an active soil process that is slowly degrading the natric horizon because of exchangeable $\mathrm{Al}^{3+}$ and $\mathrm{H}^{+}$generation and re-stabilization of the soil structure, permitting leaching of the sodium.
\end{abstract}

\section{Keywords}

Sodic Soil, Natric Horizon, Ferrolysis, Weathering, Aqualfs

\section{Introduction}

\subsection{Saline and Sodic Soils: Similarities and Differences}

Soil genesis involves evaluating the roles of: 1) parent materials, 2) climate, 3) organisms, 4) topographic position, and 5) time in the development of soils. Aridisols are soils developed in regions where the evapotranspiration exceeds the precipitation in seven out of ten years. These climatic conditions limit the percolation of water, resulting in the accumulation of soluble and difficulty soluble salts. In humid regions, water percolation through the solum typically removes soluble salts; however, some soils in humid climates do exhibit sufficient concentrations of soluble salt that alter the soil profile and its properties.

Saline, sodic and saline-sodic soils are typically located in semi-arid and arid regions; however, these soils are also less frequently located in humid regions 
[1]. The exact definitions of saline, sodic, and saline-sodic soils are based largely on experimental protocols that reveal the intensity of soil properties associated with salt concentrations [2] [3] [4]. The exchangeable sodium percentage (ESP) is a measure of the sodium concentration associated with a soil horizon's cation exchange capacity. ESP is expressed as $[\mathrm{Na}] \times 100 / \mathrm{CEC}$, where all concentrations have units of centimole proton charge per $\mathrm{kg}\left(\mathrm{cmol}_{\mathrm{p}(+)} / \mathrm{kg}\right)$, or in the older literature as milliequivalents/100g-soil (meq/100g). The sodium adsorption ratio (SAR) is generally a measure of the sodium concentration in water or saturated paste extracts. The SAR is expressed as $[\mathrm{Na}] / \sqrt{\{[\mathrm{Ca}]+[\mathrm{Mg}]\} / 2}$, where all concentrations are mole charge/liter. When the ESP is less than 50\%, the ESP and SAR frequently exhibit a linear relationship; that is, ESP $=K_{G} \times S A R$, where $K_{G}$ is the Gapon constant [2] [3] [4].

Typically soils not considered sodic, saline or saline-sodic have water saturated electrical conductivity extracts (ECe) less than $4 \mathrm{dS} \cdot \mathrm{m}^{-1}$ at $25^{\circ} \mathrm{C}$ and saturated sodium adsorption extract ratios (SARe) less than 13. Saline soils have an ECe greater than $4 \mathrm{dS} \cdot \mathrm{m}^{-1}$ and a SARe of less than 13 . Sodic soils are soils exhibiting an ECe less than $4 \mathrm{dS} \cdot \mathrm{m}^{-1}$ and a SARe of greater than 13. Typically, saline soils have an ESP of less than 15 and a $\mathrm{pH}$ less than 8.5, whereas sodic soils have an ESP of greater than 15 and a $\mathrm{pH}$ greater than 8.5 . Saline-sodic soils generally exhibit an ESP of greater than 15 and a $\mathrm{pH}$ less than 8.5 [2] [3] [4].

The natric horizon, as defined in the "Keys of Soil Taxonomy" [5], requires "1) a thickness requirement based on soil texture and the presence or absence of lamellae, 2) evidence of clay illuviation (examples include clay bridging of sand grains, clay films lining pores, clay films on both vertical and horizontal surfaces of peds), 3) a greater clay content requirement than an overlying eluvial horizon (argillic horizons), 4) typically having columnar or prismatic structures, and 5) typically having an exchangeable sodium percentage (ESP) of 15 percent or more exchangeable magnesium plus sodium than calcium plus extractable acidity". The reader is encouraged to observe the "Keys of Soil Taxonomy" for a more rigorous and precise listing of the criteria for a natric horizon. The absence of a natric horizon should not infer that plant productivity or the soil's physical properties are not influenced by the presence of sodium, as sodium intolerant plants may be negatively impacted at an ESP of less than $15 \%$. Therefore, Australia proposes an ESP greater than $6 \%$ as the significant onset for soil structure dispersion [6].

\subsection{Sodium, Calcium and Other Minerals Appropriate to This Study}

Calcite $\left[\mathrm{CaCO}_{3}\right]$, dolomite $\left[\mathrm{CaCO}_{3} \mathrm{MgCO}_{3}\right]$, gypsum $\left[\mathrm{CaSO}_{4} \cdot 2 \mathrm{H}_{2} \mathrm{O}\right]$, and magnesite $\left[\mathrm{MgCO}_{3}\right]$ are abundant minerals in the soil environment and parent materials. However, based on the water status of the soils and the weathering of primary minerals, the following minerals may also be present: nahcolite $\left[\mathrm{NaHCO}_{3}\right]$, trona $\left[\mathrm{Na}_{3} \mathrm{H}\left(\mathrm{CO}_{3}\right)_{2} \cdot 2 \mathrm{H}_{2} \mathrm{O}\right]$, sylvite $[\mathrm{KCl}]$, halite $[\mathrm{NaCl}]$, kalicinite $\left[\mathrm{KHCO}_{3}\right]$, 
thermonatrite $\left[\mathrm{Na}_{2} \mathrm{CO}_{3} \cdot \mathrm{H}_{2} \mathrm{O}\right]$, pirssonite $\left[\mathrm{CaCO}_{3} \cdot \mathrm{Na}_{2} \mathrm{CO}_{3} \cdot 2 \mathrm{H}_{2} \mathrm{O}\right]$, gaylussite $\left[\mathrm{CaCO}_{3} \cdot \mathrm{Na}_{2} \mathrm{CO}_{3} \cdot 5 \mathrm{H}_{2} \mathrm{O}\right]$. Albite, a sodium bearing silicate $\left(\mathrm{NaAlSi}_{3} \mathrm{O}_{8}\right)$, is also present in many soils and parent materials.

\subsection{Sodic Soils and Their Influence on Plant Growth}

Sodium may negatively influence plant growth and development in several distinct domains: 1) degradation of the soil's physical properties, 2) supporting alkaline to extremely alkaline $\mathrm{pH}$ values, and 3) increasing chemical activities involving sodium, molybdenum, and boron to toxic levels [2] [3] [4] [6]. Generally, if as little as 10 percent of the cation exchange complex becomes composed of sodium, then the soil's physical properties are deleteriously affected.

Soil structures are complex flocculated and aggregated entities primarily composed of sand, silt, clay, and soil organic matter. An important soil physical property that is adversely affected by sodium is the wet aggregate stability. Divalent calcium exhibits stronger phyllosilicate adsorption, subsequently reducing the diffuse layer thickness and permitting greater soil structure strength. Conversely sodium exhibits weaker phyllosilicate adsorption, subsequently increasing the diffuse layer thickness and permitting substantially weaker soil structure strength. The resulting dispersion of the soil structure permits the textural separates to migrate and reduce the soil's pore space, resulting in reduced: 1) water infiltration and percolation, 2) root penetration, and 3) aeration and gaseous exchange. The diffuse double layer (DDL) theory can predict swelling pressures in smectite systems, particularly with montmorillonite [7] [8]. Swelling pressures are effectively repulsion forces, with $\mathrm{Ca}-\mathrm{Na}$ systems showing greater macroaggregate inhibition with increasing $\mathrm{Na}$ saturation of the exchange complex.

A frequently disturbed chemical property in sodic soils is an excessively alkaline $\mathrm{pH}$. Soil $\mathrm{pH}$ increases with increased sodium activity, presumably because exchangeable $\mathrm{Na}$ acts as a Lewis acid, fostering hydrolysis and ion exchange, resulting in the generation of exchangeable $\mathrm{H}^{+}$and increased solution activities of $\mathrm{Na}^{+}$and $\mathrm{OH}^{-}$[2] [3] [6]. The hydrolytic behavior of $\mathrm{Na}$ rests with its small ionic radius and a large effective ionic radius, permitting $\mathrm{Na}^{+}$to be easily displaced from the diffuse layer by other common ionic species. Monovalent alkali cations display ionic radii patterns that support increased hydration spheres upon progression with atomic number. The hydration radius of ammonium is similar to potassium: $\mathrm{Li}<\mathrm{Na}<\mathrm{K}<\mathrm{NH}_{4}<\mathrm{Rb}<$ Cs. Compared to calcium, magnesium has a greater hydration energy, supporting a larger hydration radius. The larger magnesium hydration shell supports soil structure dispersion, whereas calcium strengthens soil structure stability [6] [7].

The development of soil alkalinity reduces the plant availability of phosphorus, iron, manganese, copper, and zinc, potentially inducing plant nutrient deficiencies. Elemental toxicity may arise from $\mathrm{pH}$-dependent plant availability of sodium, molybdenum, and boron. Boron toxicity arises from the development of soluble sodium metaborate, rather than the less soluble calcium metaborate. 
Molybdenum typically has greater plant availability in alkaline soils.

Rice (Oryza sativa) and burmuda grass (Cynodon dactylon) are considered examples of plants that are tolerant of sodic soils. Semi-tolerant plants include wheat (Triticum aestivum), barley (Hordeum vulgare) and oat (Avena sativa), whereas cowpea (Vigna unguiculata), lentil (Lens esculenta) and Maize/Corn (Zea mays) are susceptible. Sensitivity varies because of growth stage, environment (rainfall, evapotranspiration, soil drainage, and irrigation water quality), varieties, and cultural practices such as tillage and mulching [6].

\subsection{Soil Chemistry and Its Influence on Soil Properties}

Carbon dioxide will interact with water to form carbonic acid $\left(\mathrm{H}_{2} \mathrm{CO}_{3}\right)$. The equilibrium expression is:

$$
\mathrm{CO}_{2}(\mathrm{~g})+\mathrm{H}_{2} \mathrm{O}=\mathrm{H}_{2} \mathrm{CO}_{3} \quad \log \mathrm{K}=-1.46
$$

or

$$
\left[\mathrm{H}_{2} \mathrm{CO}_{3}\right] /\left[P_{\mathrm{CO}_{2}}\right]=10^{-1.46},
$$

where $P_{\mathrm{CO}_{2}}$ is the partial pressure of carbon dioxide, having a value of 413 ppm. The acid protonation reactions for carbonic acid are:

$$
\begin{array}{ll}
\mathrm{H}_{2} \mathrm{CO}_{3}=\mathrm{H}^{+}+\mathrm{HCO}_{3}^{-} & \log K_{1}=-6.36 \\
\mathrm{HCO}_{3}=\mathrm{H}^{+}+\mathrm{CO}_{3}^{2-} & \log K_{2}=-10.33
\end{array}
$$

Substitution of the $\mathrm{H}_{2} \mathrm{CO}_{3}$ protonation reaction will provide a $\mathrm{pH}$ of 5.6. Rainfall, which has not been influenced by oxides of nitrogen and sulfur and other anthropogenic species, is acidic.

Weathering reactions are thermodynamic predictable reactions involving earth minerals. Congruent weathering involves the dissolution of solid minerals, an example being the dissolution of calcite to $\mathrm{Ca}^{2+}$ and bicarbonate, which is expressed as:

$$
\mathrm{CaCO}_{3}+\mathrm{H}_{2} \mathrm{O}+\mathrm{CO}_{2}=\mathrm{Ca}^{2+}+2 \mathrm{HCO}_{3}^{-} .
$$

Incongruent weathering involves the conversion of a mineral to another mineral. Important to this study is the incongruent weathering of albite $\left[2 \mathrm{NaAlSi}_{3} \mathrm{O}_{8}(\mathrm{~s})\right]$. Three examples of the incongruent weathering reactions involving albite include: 1) hydrolysis, 2) carbonation, and 3) oxalic acid, which is an example of an organic acid emanating by plant roots.

1) Hydrolysis

$$
\begin{aligned}
& 2 \mathrm{NaAlSi}_{3} \mathrm{O}_{8}(\mathrm{~s})+11 \mathrm{H}_{2} \mathrm{O} \\
& =2 \mathrm{Na}^{+}+2 \mathrm{OH}^{-}+4 \mathrm{H}_{4} \mathrm{SiO}_{4}\left[\text { silicic acid] }+\mathrm{Al}_{2} \mathrm{Si}_{2} \mathrm{O}_{5}(\mathrm{OH})_{4}(\mathrm{~s})[\text { kaolinite }]\right.
\end{aligned}
$$

2) Carbonation

$$
\begin{aligned}
& 2 \mathrm{NaAlSi}_{3} \mathrm{O}_{8}(\mathrm{~s})+2 \mathrm{CO}_{2}+11 \mathrm{H}_{2} \mathrm{O} \\
& =2 \mathrm{Na}^{+}+2 \mathrm{HCO}_{3}^{-}+4 \mathrm{H}_{4} \mathrm{SiO}_{4}+\mathrm{Al}_{2} \mathrm{Si}_{2} \mathrm{O}_{5}(\mathrm{OH})_{4}(\mathrm{~s})
\end{aligned}
$$


3) Albite weathering by oxalic acid (dicarboxylic acid):

$$
\begin{aligned}
& 2 \mathrm{NaAlSi}_{3} \mathrm{O}_{8}(\mathrm{~s})+\mathrm{H}_{2} \mathrm{C}_{2} \mathrm{O}_{4}+9 \mathrm{H}_{2} \mathrm{O} \\
& =2 \mathrm{Na}^{+}+\mathrm{C}_{2} \mathrm{O}_{4}^{2-}+4 \mathrm{H}_{4} \mathrm{SiO}_{4}+\mathrm{Al}_{2} \mathrm{Si}_{2} \mathrm{O}_{5}(\mathrm{OH})_{4}(\mathrm{~s})
\end{aligned}
$$

In soil environments that experience leaching, soluble silicic acid may be removed from the system, supporting the weathering of albite to kaolinite. The influence of rainfall over protracted time periods supports congruent and incongruent weathering. Plant acids, particularly present in the root rhizosphere, similarly support weathering [6] [8].

\subsection{Ferrolysis}

First proposed by Brinkman [9], ferrolysis is mostly observed when seasonal wetting and drying cycles create alternating anoxic and oxic soil environments, which in turn, create sufficient acidity to degrade primary and secondary (phyllosilicate) minerals. In anoxic soil environments, carbon sources $\left(\mathrm{CH}_{2} \mathrm{O}\right)$ and microbial populations respond with $\mathrm{Fe}$-oxyhydroxides to produce ferrous iron $\left(\mathrm{Fe}^{2+}\right)$ :

$$
\mathrm{CH}_{2} \mathrm{O}+4 \mathrm{Fe}(\mathrm{OH})_{3}+7 \mathrm{H}^{+}=4 \mathrm{Fe}^{2+}+\mathrm{HCO}_{3}^{-}+10 \mathrm{H}_{2} \mathrm{O} \text {. }
$$

Carbon sources include particulate soil organic matter, mineralized humus, microbial or plant exuded organic acids, and other compounds. Ferrous iron $\left(\mathrm{Fe}^{2+}\right)$ will adsorb onto the soil's cation exchange complex, displacing $\mathrm{Ca}^{2+}, \mathrm{Mg}^{2+}$, and $\mathrm{K}^{+}$. Upon the establishment of an oxic soil environment, $\mathrm{Fe}^{2+}$ will oxidize to form Fe-oxyhydroxides, resulting in distinct zones of iron accumulation and depletion and the creation of soil acidity. The oxidation of Fe and creation of acidity may be represented as:

$$
4 \mathrm{Fe}^{2+}+\mathrm{O}_{2}+10 \mathrm{H}_{2} \mathrm{O}=4 \mathrm{Fe}(\mathrm{OH})_{3}+8 \mathrm{H}^{+} .
$$

The establishment of active and reserve acidity should accentuate incongruent weathering; however, incongruent weathering of one phyllosilicate (montmorillonite) to another (kaolinite) may not readily occur [10].

\subsection{Purpose of Manuscript}

The purpose of this manuscript is: 1) to present an in-depth review of sodium bearing soils in a humid continental climate (southeastern Missouri) and 2) to provide an assessment of the soil processes involved in sodic soil genesis.

\section{Materials and Methods}

\subsection{The Geologic History of the Study Area}

The study area comprises the southeastern portion of Missouri and the northeastern portion of Arkansas within the Mississippi Embayment (Middle Mississippi River Alluvial Valley). The geologic history of the study area is complex, with multiple episodes of Pleistocene-Holocene valley entrenchment and deposition [11]. The Advance lowlands occupy areas between the Ozark Border region and Crowley's Ridge in southeastern Missouri and northeastern Arkansas. 
Within the Advance Lowlands, Roxanna loess (Altonian at 55,000 yr BP) and Peoria loess (Woodfordian at 20,000 yr BP) have been identified [12] [13] [14] [15] [16]. In Arkansas, West et al. [12] documented that Crowley's Ridge loess was a succession of Peoria loess, Roxana loess and Loveland loess. The younger Peoria and Roxana loess sheets had an eastern source area, whereas the older Loveland loess had its source area in the Advance Lowlands. Rutledge et al. [13] investigated silty braided stream terraces in the Advance Lowlands, documenting that Peoria loess was superimposed on Loveland loess. West and Rutledge [14] investigated several silty sites in the Advance Lowlands and determined the source materials to be alluvium.

In Arkansas, Saucier [11] proposed that the Advance Lowlands have Peoria loess superimposed on Roxana loess, presumably on early or middle Wisconsin valley train. Subsequently, Blum et al. [15] using similar transects reinterpreted the valley train ages from middle Wisconsin to late Wisconsin. Royall et al. [16] suggested that extensive river meandering during or around 12,000 yr BP produced extensive areas of backswamp. By $9000 \mathrm{yr}$ BP, the Mississippi River occupied a position along Sikeston Ridge. Approximately 9000 yr BP, the Mississippi River diverted through Thebes Gap and flowed east of Sikeston Ridge, occupying its modern location [16] [17].

\subsection{Climatic Evolution in Southeastern Missouri}

Royall et al. [16] documented pollen assemblages in the Missouri Advance Lowlands. Between 14,500 to $18,000 \mathrm{yr} \mathrm{BP}$, pollen assemblages indicate a boreal forest consisting of spruce (Picea) and northern pine (Dploxylon Pinus), fir (Abies) and minor stands of Tamarack (Larix laricina). Broadleaf representation consisted of oak (Quercus) and willow (Salix). With warming conditions (9500 to $14,500 \mathrm{yr} \mathrm{BP}$ ), the pollen assemblages indicate a large oak, hickory (Carya) and hornbeam (Carpinus) population increase, suggesting the conversion of a boreal forest to a mixed conifer-northern hardwood forest. With continued warming (4500 to $9500 \mathrm{yr}$ BP), oak and ash (Fraxinus) populations increased and the first recognized presence of bald cyprus (Taxodium distichum). The fine-grained sediments also indicated that silt and clays were being deposited from the Salem Plateau by flooding rivers. Willow, elm (Ulmus), sweetgum (Liquidambar), red maple (Acer rubrum) and locust (Gleditsia) dominated the landscape between $4500 \mathrm{yr}$ BP to the present and oak declined in importance.

Currently, the mean annual temperature is $13^{\circ} \mathrm{C}\left(56^{\circ} \mathrm{F}\right)$, and mean annual precipitation is $1118 \mathrm{~mm}$ (44 inches). Approximately $53 \%$ of the rainfall occurs from April to September. The average winter temperature is $4.4^{\circ} \mathrm{C}\left(40^{\circ} \mathrm{F}\right)$ and the average summer temperature is $26^{\circ} \mathrm{C}\left(79^{\circ} \mathrm{F}\right)$. The average daily summer maximum is $33^{\circ} \mathrm{C}\left(91^{\circ} \mathrm{F}\right)$ [18].

\subsection{Sodic Soils in Missouri}

Of the many soil series within the study area, the emphasis will be placed on 
three aqualfs. The Overcup series (fine, smectitic, thermic Vertic Albaqualfs) consists of very deep, poorly drained, very slowly permeable soils that formed in fine-textured alluvium. These soils are on broad low-lying terraces in the Advance Lowlands. The horizon sequence is Ap (ochric) - Eg (albic) - Btg (argillic) - Cg. The Foley series (fine-silty, mixed, active, thermic Albic Glossic Natraqualfs) consists of very deep, poorly drained, very slowly permeable soils that formed in silty terraces. The horizon sequence is Ap (ochric) - Eg (Albic) - B/E (B is argillic) - Btng (natric) - BCng (natric). The Lafe series (fine-silty, mixed, active, thermic Glossaquic Natrudalfs) consists of very deep, somewhat poorly drained, very slowly permeable soils that formed in silty Pleistocene terraces. The horizon sequence is Ap (ochric) - Eg-BE (Albic) - Btng (natric) - BCng (natric) [19]. The important phyllosilicates in the clay separate are smectite (montmorillonite), followed by hydroxy Al-interlayered vermiculite, hydrous mica (Illite), and minor quantities of kaolinite [1]. The Foley series spans 133,950 ha across the states of Arkansas, Missouri, and Louisiana, with Arkansas having the largest areal extent. In western Dunklin County, Missouri, the Foley series spans 982 ha and the Lafe series spans 170 ha. Correspondingly, the Overcup series spans 6615 ha.

\subsection{Laboratory Methods}

Soil pedons were sampled in excavated pits and the soil profile descriptions were according to US Department of Agriculture criteria [20]. Soil $\mathrm{pH}$ in water, $\mathrm{NH}_{4-}$ Acetate ( $\mathrm{pH}$ 7) exchangeable cations ( $\mathrm{Ca}, \mathrm{Mg}, \mathrm{K}$ and $\mathrm{Na}$ ), and $\mathrm{BaCl}_{2}$-triethanolamine (pH 8.0) acidity are routine soil characterization procedures (Carter, 1993). Soil organic matter by loss on ignition, Bray-1 phosphorus, and $2 \mathrm{M} \mathrm{KCl}$ extractable $\mathrm{SO}_{4}$-S were also determined by the University of Missouri Soil Testing Laboratory. The clay, silt, and sand fractions were fractionated by Na-saturation of the exchange complex, washed with water-methanol mixtures, dispersed in $\mathrm{Na}_{2} \mathrm{CO}_{3}$ ( $\mathrm{pH}$ 9.2), followed by centrifuge fractionation and wet sieving [21].

An aqua regia digestion was employed to obtain a near total estimation of elemental abundance associated with all but the most recalcitrant soil chemical environments. Aqua-regia does not appreciably degrade quartz, albite, orthoclase and other minerals; however, anorthite and phyllosilicates are partially digested. Homogenized samples $(0.75 \mathrm{~g})$ were equilibrated with 0.01 liter of aqua-regia ( 3 mole nitric acid: 1 mole hydrochloric acid) in a $35^{\circ} \mathrm{C}$ incubator for 24 hours. Samples were shaken, centrifuged and filtered $(0.45 \mu \mathrm{m})$, with a known aliquot volume analyzed using inductively coupled plasma emission - mass spectrometry. Selected samples were duplicated, and known reference materials were employed to guarantee analytical accuracy.

\section{Results}

All pedons exhibit an ochric - albic - argillic or natric horizon sequences. The 
argillic horizons for all pedons exhibit medium to course, moderate subangular blocky structures. Munsell soil colors (low chroma) indicate gleyed (g) soil conditions. The expression of Fe-oxyhydroxide accumulations and depletions and the presence of glabules ( $\mathrm{Fe}$ and $\mathrm{Mn}$ concretions) indicate seasonal and fluctuating water tables. The clay percentages abruptly increase from silt loam to silty clay loam on transition from the albic to argillic or natric horizons (Table 1). The natric horizon in the Foley pedon exhibits smaller clay percentages than the overlying argillic horizon, which is not in accordance with the definition for natric horizons. The usage of natric horizon remains appropriate because clay illuviation appears to be supported by dispersion of the thick E and EBg horizons.

The ochric epipedons range from strongly acid to moderately acid for the Overcup pedons and have neutral $\mathrm{pH}$ values for the Foley and Lafe pedons (Table 2). The upper argillic horizons range from moderately acid to extremely acid for the Overcup pedons and extremely acid for the Foley pedon and moderately acid for the Lafe pedon. The deeper portions of the argillic horizons range from neutral to mildly alkaline for the Overcup pedons and range from alkaline to very strongly alkaline in the Foley and Lafe pedons, respectively. The cation exchange capacities (CEC) in the eluvial horizons of the Overcup pedons range from low to moderate, whereas the illuvial horizons generally express high cation exchange capacities. The eluvial horizons of the Foley and Lafe pedons demonstrate low to moderate cation exchange capacities, whereas the illuvial horizons range from moderate to high. In all pedons, the CEC values parallel clay contents. The exchangeable sodium percentages (ESP) are greater in the illuvial horizons and are greatest for the Lafe pedon, corresponding with the most alkaline $\mathrm{pH}$ values. The exchangeable $\mathrm{Ca} / \mathrm{Mg}$ ratios are greatest in the eluvial horizons, with the Foley argillic horizons having the smallest ratios.

It is important to document that each pedon has a portion of its argillic horizon that has an acidic reaction, yet exhibits an elevated exchangeable sodium percentage. Each of these sodium rich and acidic Bt horizons transition to a deeper portion of the argillic horizons with greater ESP values and an alkaline to strongly alkaline reaction. It is suspected that the considerable presence of $\mathrm{Al}^{3+}$ and $\mathrm{H}^{+}$on the cation exchange complex offsets the dispersive capacity of sodium, supporting the downward migration of soluble anions that promote an acidic $\mathrm{pH}$ in the upper Bt horizons.

The aqua regia digestion was performed for the Overcup \#1 pedon and the Foley pedon. For reference purposes $1000 \mathrm{mg} \mathrm{Na} \mathrm{kg}^{-1}$ from the aqua regia digestion corresponds to $4.35 \mathrm{cmol} \mathrm{Na} \mathrm{kg}^{-1}$ if all the aqua regia digestion sodium values were converted to an exchangeable sodium basis. The aqua regia digestion will to a very limited extent degrade albite, thus if albite remains in the soil environment, then any sodium present in the lattice of albite will not be quantitatively detected. The relationship between exchangeable sodium and aqua regia digestion sodium for the Foley pedon is highly significant (Figure 1). Additionally, 
Table 1. Selected soil chemical properties.

\begin{tabular}{|c|c|c|c|c|}
\hline Horizon & Depth $(\mathrm{cm})$ & Texture & Clay (\%) & Silt (\%) \\
\hline \multicolumn{5}{|c|}{ Overcup \#1 } \\
\hline Ap & 18 & silt loam & 15 & 76 \\
\hline Eg & 25 & silt loam & 20 & 68 \\
\hline Btg1 & 43 & silty clay & 41 & 57 \\
\hline Btg2 & 71 & silty clay & 40 & 56 \\
\hline Btg3 & 99 & silty clay loam & 36 & 59 \\
\hline Btg 4 & 129 & silty clay loam & 31 & 63 \\
\hline Btg5 & 157 & silt loam & 25 & 71 \\
\hline $\mathrm{BCg}$ & 200 & silt loam & 18 & 77 \\
\hline \multicolumn{5}{|c|}{ Overcup \#2 } \\
\hline A & 10 & silt loam & 12 & 70 \\
\hline $\mathrm{E}$ & 31 & silt loam & 14 & 69 \\
\hline $\mathrm{BE}$ & 46 & silt loam & 17 & 67 \\
\hline Bt1 & 61 & silty clay loam & 32 & 57 \\
\hline Btg2 & 76 & silty clay loam & 31 & 56 \\
\hline Btg3 & 94 & silty clay loam & 33 & 54 \\
\hline Btg4 & 112 & silty clay loam & 37 & 58 \\
\hline Btg5 & 153 & silty clay loam & 29 & 61 \\
\hline \multicolumn{5}{|c|}{ Foley } \\
\hline Ap & 18 & silt loam & 11 & 57 \\
\hline Eg & 30 & silt loam & 13 & 57 \\
\hline $\mathrm{EBg}$ & 51 & silt loam & 15 & 62 \\
\hline Btg1 & 76 & silty clay loam & 34 & 52 \\
\hline Btg2 & 91 & silty clay loam & 31 & 51 \\
\hline Btng1 & 109 & silt loam & 24 & 58 \\
\hline Btng2 & 135 & silt loam & 26 & 66 \\
\hline Btng3 & 178 & silt loam & 27 & 67 \\
\hline \multicolumn{5}{|c|}{ Lafe } \\
\hline Ap & 5 & silt loam & 14 & 80 \\
\hline $\mathrm{Eg}$ & 21 & silt loam & 21 & 73 \\
\hline $\mathrm{BEg}$ & 30 & silt loam & 36 & 61 \\
\hline Btng1 & 61 & silty clay loam & 39 & 56 \\
\hline Btng2 & 101 & silty clay loam & 33 & 64 \\
\hline Btng3 & 142 & silty clay loam & 43 & 53 \\
\hline Btng4 & 157 & silty clay loam & 62 & 38 \\
\hline
\end{tabular}


Table 2. Selected soil chemical properties.

\begin{tabular}{|c|c|c|c|c|c|}
\hline Horizon & $\mathrm{pH}$ & CEC & BS \% & ESP \% & $\mathrm{Ca} / \mathrm{Mg}$ \\
\hline \multicolumn{6}{|c|}{ Overcup \#1 } \\
\hline Ap & 5.4 & 8.2 & 82 & 1.0 & 2.6 \\
\hline Eg & 6.2 & 8.4 & 83 & 3.5 & 2.5 \\
\hline Btg1 & 4.2 & 23.9 & 39 & 3.3 & 2.2 \\
\hline Btg2 & 4.1 & 25.5 & 39 & 5.7 & 1.9 \\
\hline Btg3 & 4.7 & 21.6 & 58 & 9.5 & 1.7 \\
\hline Btg4 & 7.1 & 19.8 & 87 & 13.8 & 1.7 \\
\hline Btg5 & 7.5 & 15.0 & 100 & 14.2 & 1.7 \\
\hline $\mathrm{BCg}$ & 7.1 & 13.4 & 100 & 13.3 & 1.7 \\
\hline \multicolumn{6}{|c|}{ Overcup \#2 } \\
\hline A & 6.0 & 15.1 & 57 & 0.8 & 2.6 \\
\hline $\mathrm{E}$ & 5.1 & 12.8 & 46 & 0.7 & 2.3 \\
\hline $\mathrm{BE}$ & 5.2 & 14.8 & 29 & 2.1 & 1.0 \\
\hline Bt1 & 5.6 & 20.4 & 31 & 6.7 & 1.0 \\
\hline Btg2 & 5.1 & 29.4 & 58 & 9.8 & 1.5 \\
\hline Btg3 & 5.4 & 24.9 & 80 & 13.8 & 1.8 \\
\hline Btg4 & 6.5 & 21.0 & 100 & 18.3 & 2.1 \\
\hline Btg5 & 7.3 & 21.3 & 100 & 16.3 & 1.5 \\
\hline \multicolumn{6}{|c|}{ Foley } \\
\hline Ap & 6.6 & 10.5 & 100 & 1.3 & 2.7 \\
\hline Eg & 6.5 & 8.4 & 100 & 2.0 & 2.2 \\
\hline $\mathrm{EBg}$ & 5.5 & 10.5 & 82 & 4.6 & 1.2 \\
\hline Btg1 & 3.7 & 24.2 & 41 & 5.0 & 0.6 \\
\hline Btg2 & 4.6 & 24.0 & 51 & 9.8 & 0.3 \\
\hline Btng1 & 6.3 & 17.2 & 84 & 19.1 & 0.3 \\
\hline Btng2 & 7.7 & 16.0 & 100 & 24.2 & 0.2 \\
\hline Btng3 & 7.9 & 15.5 & 100 & 24.8 & 0.3 \\
\hline \multicolumn{6}{|c|}{ Lafe } \\
\hline Ap & 7.3 & 10.4 & 99 & 5.0 & 1.3 \\
\hline $\mathrm{Eg}$ & 4.9 & 12.1 & 98 & 7.4 & 1.5 \\
\hline $\mathrm{BEg}$ & 4.8 & 13.5 & 73 & 18.9 & 1.1 \\
\hline Btng1 & 5.9 & 25.3 & 98 & 37.6 & 1.0 \\
\hline Btng2 & 8.3 & 26.2 & 100 & 36.0 & 1.1 \\
\hline Btng3 & 8.6 & 26.8 & 100 & 35.1 & 0.9 \\
\hline Btng4 & 9.7 & 36.8 & 100 & 35.7 & 1.0 \\
\hline
\end{tabular}

CEC is cation exchange capacity ( $\mathrm{cmol}$ charge $/ \mathrm{kg}$ ), BS \% is percent base saturation, ESP \% is exchangeable sodium percentage. 


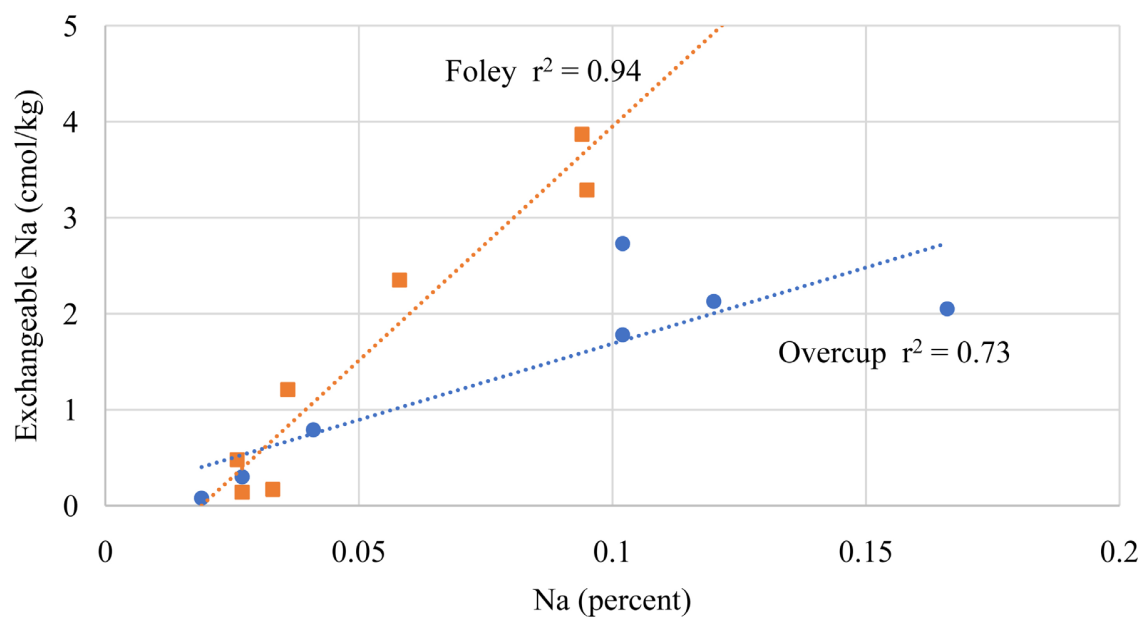

Figure 1. Relationship involving exchangeable sodium and aqua regia digestion sodium.

the sodium content measured from the aqua regia digestion is roughly equivalent to the exchangeable sodium content across the horizons of the soil profile. The relationship involving the Overcup pedon is less precise, suggesting that a minor percentage of sodium may exist in an aqua regia digestible mineralogy in addition to the sodium allocation as exchangeable sodium.

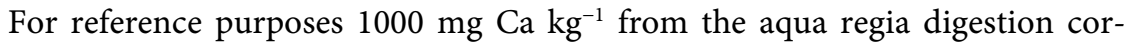
responds to $5 \mathrm{cmol} \mathrm{Ca} \mathrm{kg}^{-1}$ if all the calcium was converted to an exchangeable calcium basis. The calcium aqua regia digestion concentrations range from equivalent to slightly greater than the experimental determined exchangeable calcium concentrations, suggesting that some calcium-bearing crystalline material exists. The aqua regia digestion will partially degrade anorthite $\left(\mathrm{CaAl}_{2} \mathrm{Si}_{2} \mathrm{O}_{8}\right)$; however, anorthite is rare and exists largely in mafic Precambrian rocks. More likely, some small percentage of the calcium may exist in a few, small microenvironments as calcite, gypsum or calcium phosphate.

\section{Soil Genesis of Sodium Bearing Soils}

It is commonly acknowledged that soil evolution may be predicated on correctly ascertaining the specific attributes of five soil forming factors: 1) parent material, 2) climate, 3) organisms, 4) topography, and 5) time. If soils are commingled across the landscape, then in many circumstances, some of the soil forming factors are more important in predicting differences in soil profile appearances and soil behavior.

Soil mapping reveals that the Overcup-Foley-Lafe soils form a mosaic across the landscape. The Foley series is slightly more elevated in the landscape (commonly 5 to $15 \mathrm{~cm}$ ). Regardless, much of the landscape has been precision land graded for furrow or flood irrigation. Thus, the limited landscape topographic differences do not effectively support soil divergence in their genesis. Similarly, climate and organisms do not appear to be the dominate soil forming factors that reveal soil profile evolutionary differences. All soils have thermic tempera- 
ture regimes; thus, temperatures differences are not sufficiently different to foster evolutional differences. It should be noted that ancestral forest growth is an unknown influence; in that, the depth to the fluctuating water table and the thickness of the rooting zone would be tree species dependent and influenced by the depth to the upper portion of the natric horizon [6]. The Lafe and Foley pedons have tongues of albic materials degrading the uppermost portion of argillic horizons. Given the slight elevation differences and the tongues of albic material infer that these pedons occupy older silty terrace positions and the Crowley pedons occupy lower topographic silty terraces [18]. Currently, the entire forest cover has been removed because of crop production [18] [22]. The study area has been artificially drained by a series of water diversion structures and drainage ditches [22].

The influence of parent material is integral to the discerning soil profile differences. The Overcup series has a fine-textured control section, whereas the Foley and Lafe soil series have a fine-silty control section. Thus, for the Overcup and Foley/Lafe soils, either the textural composition of the alluvium is different, or the alluvium depositional environments are different. The timing of the depositional environments is also relevant. All the investigated soils have well developed argillic horizons, whereas soils east of Crowley's Ridge lack argillic horizons. As previously noted, the ancestral Mississippi River abandoned the Advance Lowlands to begin entrenchment and sedimentation east of Crowley's Ridge [11] [12] [13] [14] [15]. Thus, these soils in the Advance Lowlands are older than the Morehouse Lowland soils east of Crowley's Ridge, with a time differential to permit argillic horizon development [18].

It is probable that the fine-silty alluvium in the Foley and Lafe was deposited as terrace material, with the fine-textured material in the Overcup deposited as backswamp. The fine-silty alluvium originated from stream transported from erosion of the thick loess mantles of the Salem Plateau, possibly co-mixed with areal deposition of loess [18]. Conversely the fine textured alluvium likely had its source from the ancestral Mississippi River.

\section{Ancestral and Contemporary Soil Processes That Contribute to Soil Profile Expression}

The soils are aqualfs, thus these soils are poorly drained or somewhat poorly drained, slowly permeable, and exhibit seasonal episodes of suboxic to anoxic reduction. Soil profile redoximorphic features include $\mathrm{Mn}$ - and Fe-oxyhydroxide accumulations and depletions, presence of glabules, and low chroma soil colors (gleyed). Given seasonal oxidation and reduction episodes, leaching and ferrolysis are active soil processes. Ferrolysis is involved in creating $\mathrm{Mn}$ - and Fe-oxyhydroxide accumulations and depletions, displacement of $\mathrm{Ca}, \mathrm{Mg}, \mathrm{K}$, and $\mathrm{Na}$ from cation exchange sites, and the development of soil acidity.

$\mathrm{The} \mathrm{Ca} / \mathrm{Mg}$ ratio is smaller in the Foley and Lafe pedons than for the Overcup pedons, indicating than soil structure degradation because of dispersion is fa- 
vorable (Table 2 and Table 3) [2] [4] [6]. The presence of greater ESP values for the Lafe and Foley pedons further suggest enhanced soil structure degradation, dispersion, and water percolation restrictions. Soil acidification supports the incongruent weathering of albite to montmorillonite and ultimately to kaolinite, providing a source of sodium from albite and a source of aluminum and magnesium from phyllosilicates.

The Foley genesis sequence involves poorly-drained alluvial deposition where: 1) seasonal anoxic conditions orchestrate Fe-oxyhydroxide accumulation and depletion, gleyed soil conditions and cation leaching, 2) ferrolysis contributes to the acidic soil regime, and 3) clay eluviation-illuviation creates argillic horizons. Sodium accumulation because of mineral weathering supports 1) an alkaline $\mathrm{pH}$ and 2) an elevated exchangeable sodium percentage, 3) soil structure dispersion, and 4) natric horizon formation. Continued ferrolysis encourages soil acidification and sodium displacement from the exchange complex and reduction of the exchangeable sodium percentage, and because of increased $\mathrm{Al}^{3+}$ and $\mathrm{H}^{+}$ re-constitution of the soil structure. Thus, the acidic upper portion argillic horizon represents degradation of the natric horizon to non-sodic argillic horizon.

The Overcup series did not have sufficient albite to create natric horizons, except for the lower most horizons of the Overcup pedon, which shared similar alluvium with the Foley pedons. The Lafe series lags behind the Foley series in the reduction of the natric horizon to a non-sodic argillic horizon.

Table 3. Selected aqua regia digestion alkaline earth and alkali elements.

\begin{tabular}{ccccc}
\hline \multirow{3}{*}{ Horizon } & Calcium & Magnesium & Potassium & Sodium \\
\cline { 2 - 5 } & \multicolumn{3}{c}{$\mathrm{mg} \cdot \mathrm{kg}^{-1}$} \\
Ap & 1100 & 1400 & 1300 \\
Eg & 1200 & 1500 & 1200 & 270 \\
Btg1 & 1200 & 2400 & 1700 & 410 \\
Btg3 & 1400 & 2700 & 1900 & 1660 \\
Btg4 & 2300 & 4300 & 2300 & 1020 \\
Btg5 & 3400 & 4300 & 2200 & 1200 \\
BCg & 3100 & 3800 & 1900 & 1020 \\
\hline Ap & 5100 & Foley & & 270 \\
Eg & 3100 & 2900 & 1900 & 330 \\
EBg & 2200 & 3000 & 2100 & 260 \\
Btg1 & 1300 & 3500 & 1700 & 360 \\
Btng1 & 600 & 4000 & 2600 & 580 \\
Btng2 & 700 & 5900 & 2900 & 950 \\
Btng3 & 1600 & 6500 & 3800 & 940 \\
\hline
\end{tabular}




\section{Soil Behavior}

The dominant row crops in the study area are rice (Oryza sativa) and soybeans (Glycine max). Rice is not affected by the presence of natric horizons because of the shallow root systems. Conversely, in some instances soybeans are severely impacted when their root systems encounter natric horizons, particularly for the Lafe soil series. Regardless, excessive water during the growing season is a serious agricultural issue.

\section{Conclusions}

This study was conducted to present an in-depth review of sodium bearing soils in a humid continental climate and to describe soil processes involved in sodic soil evolution. Sodic soils having natric horizons exist in alluvial basins commingled with other Aqualfs. The source of the sodium presumably is the weathering of sodic plagioclase minerals. Subsequent soil structure dispersion limits sodium leaching.

Seasonal water table fluctuation is involved in creating redoximorphic features and gleyed soil conditions associated with $\mathrm{Fe}$-oxyhydroxide migrations to create zones of $\mathrm{Fe}$-accumulation and Fe-depletion. Ferrolysis supports the creation of soil acidity, responsible for reducing the soil's base saturation and facilitating soil structure stability, a process that converts the natric horizon to a non-sodic argillic horizon.

\section{Conflicts of Interest}

Author has no conflict of interest.

\section{References}

[1] Aide, M.T. (1987) Naturally Occurring Soil Soils in Southeast Missouri. Transactions of the Missouri Academy of Science, 21, 131-139.

[2] Shainberg, I. and Letey, J. (1984) Response of Soils to Sodic and Saline Conditions. Hilgardia, 52, 1-57 https://doi.org/10.3733/hilg.v52n02p057

[3] Sumner, M.E. and Naidu, R. (1998) Sodic Soils: Distribution, Properties, Management, and Environmental Consequences. Oxford University Press, Oxford.

[4] Joshi, D.C. (2012) Sodic Soils of Arid Region: Genesis, Characteristics and Management. Current Agriculture, 36, 19-27.

[5] Soil Survey Staff (2014) Keys to Soil Taxonomy. 12th Edition, USDA-Natural Resources Conservation Service, Washington DC. https://www.nrcs.usda.gov/wps/portal/nrcs/detail/soils/survey/class/taxonomy/?cid $=\mathrm{nrcs} 142 \mathrm{p} 2053580$

[6] Bui, E.N. (2017) Causes of Soil Salinization, Sodification, and Alkalinization. $\mathrm{OX}^{-}$ ford Research Encyclopedia of Environmental Science. https://doi.org/10.1093/acrefore/9780199389414.013.264

[7] Van Olphen, H. (1977) An Introduction of Colloid Chemistry. 2nd Edition. John Wiley Sons, New York.

[8] Bresler, B., McNeal, B.I. and Carter, D.L. (1982) Principles, Dynamics, Modeling. 
Springer-Verlag, Berlin.

[9] Brinkman, R. (1970) Ferrolysis, a Hydromorphic Soil Forming Process. Geoderma, 3, 100-206. https://doi.org/10.1016/0016-7061(70)90019-4

[10] De Oliveira, J.D., Chiapini, M., do Nascimento, A.F., Couto, E.G., Beirigo, R.M. and Torrado, P.V. (2017) Genesis and Classification of Sodic Soils in the Northern Pantanal. Revista Brasileira de Ciência do Solo, 41, Article ID: e0170015. https://doi.org/10.1590/18069657rbcs20170015

[11] Saucier, R.T. (1994) Geomorphology and Quaternary Geologic History of the Lower Mississippi Valley. U.S. Army Corps. Engineers, Waterways Experimental Station, Vicksburg.

[12] West, L.T., Rutledge, E.M. and Barber, D.M. (1980) Sources and Properties of Loess Deposits on Crowley's Ridge in Arkansas. Soil Science Society of America Journal, 44, 353-358. https://doi.org/10.2136/sssaj1980.03615995004400020029x

[13] Rutledge, E.M., West, L.T. and Omakupt, M. (1985) Loess Deposits on a Pleistocene Age Terrace in Eastern Arkansas. Soil Science Society of America Journal, 49, 1231-1238. https://doi.org/10.2136/sssaj1985.03615995004900050032x

[14] West, L.T. and Rutledge, E.M. (1987) Silty Deposits of a Low, Pleistocene-Age Terrace in Eastern Arkansas. Soil Science Society of America Journal, 51, 709-715. https://doi.org/10.2136/sssaj1987.03615995005100030027x

[15] Blum, M.D., Gluccione, M.J., Wysocki, D.A., Robnett, P.C. and Rutledge, E.M. (2000) Late Pleistocene Evolution of the Lower Mississippi River Valley, Southern Missouri to Arkansas. GSA Bulletin, 112, 221-235. https://doi.org/10.1130/0016-7606(2000)112\%3C221:LPEOTL\%3E2.0.CO;2

[16] Royall, P.D., Delcourt, P.A. and Delcourt, H.R. (1991) Late Quaternary Paleoecology and Paleoenvironments of the Central Mississippi Alluvial Valley. GSA Bulletin, 103, 157-170. https://doi.org/10.1130/0016-7606(1991)103\%3C0157:LQPAPO\%3E2.3.CO;2

[17] Robnett, P.C. (1997) Late Quaternary Occupation and Abandonment of the Western Lowlands Valley Train Course in Favor of the Eastern Lowlands Valley Train Course, Mississippi River, Southeastern Missouri. Master's Thesis, Southern Illinois State University, Carbondale.

[18] Gurley, P.D. (1979) Soil Survey Dunklin County, Missouri. United States Department Agriculture-Soil Conservation Service, U.S. Government Publishing Office, Washington DC.

[19] Soil Survey Staff (2021) Official Soil Series Descriptions. Natural Resources Conservation Service, United States Department of Agriculture.

https://www.nrcs.usda.gov/wps/portal/nrcs/detail/soils/survey/geo/?cid=nrcs142p2 053587

[20] Soil Survey Division Staff (1993) Soil Survey Manual. USDA Handbook No. 18. U.S. Government Publishing Office, Washington DC.

[21] Carter, M.R. (1993) Soil Sampling and Methods of Analysis. Lewis Publication, Boca Raton.

[22] Aide, M.T., McVay, B., Braden, I.S. and Aide, C. (2018) A Large-Scale Wetland Conversion Project in Southeastern Missouri: Sustainability of Water and Soil. In: Gokce, D.K., Ed., Wetlands Management: Assessing Risk and Sustainable Solutions, IntechOpen, London, UK. https://doi.org/10.5772/Intechopen.76596 